\title{
Royal Palm Bug, Xylastodoris luteolus Barber (Insecta: Hemiptera: Thaumastocoridae) ${ }^{1}$
}

\author{
T. J. Weissling, F. W. Howard, and A. W. Meerow ${ }^{2}$
}

\section{Introduction}

Cuban royal palms (Roystonea regia) are native to Florida and Cuba. In Florida, royal palm distribution is limited to the southern third of the peninsula. One of the few arthropods that feed on Roystonea regia is the royal palm bug, Xylastodoris luteolus. The royal palm bug feeds only on Roystonea regia and thus, the range of its host plant limits its distribution in Florida and Cuba. This species is the only representative of the small tropical family of Thaumastocoridae in North America.

\section{Description}

The royal palm bug is very small, with the adult reaching a length of only $2.5 \mathrm{~mm}$ (less than $1 / 10$ th of an inch). Its general body shape is elongate-oval and it is somewhat flattened. Adults are pale yellow-green in color except for the eyes which are red. The immatures look similar to the adults, but lack wings.

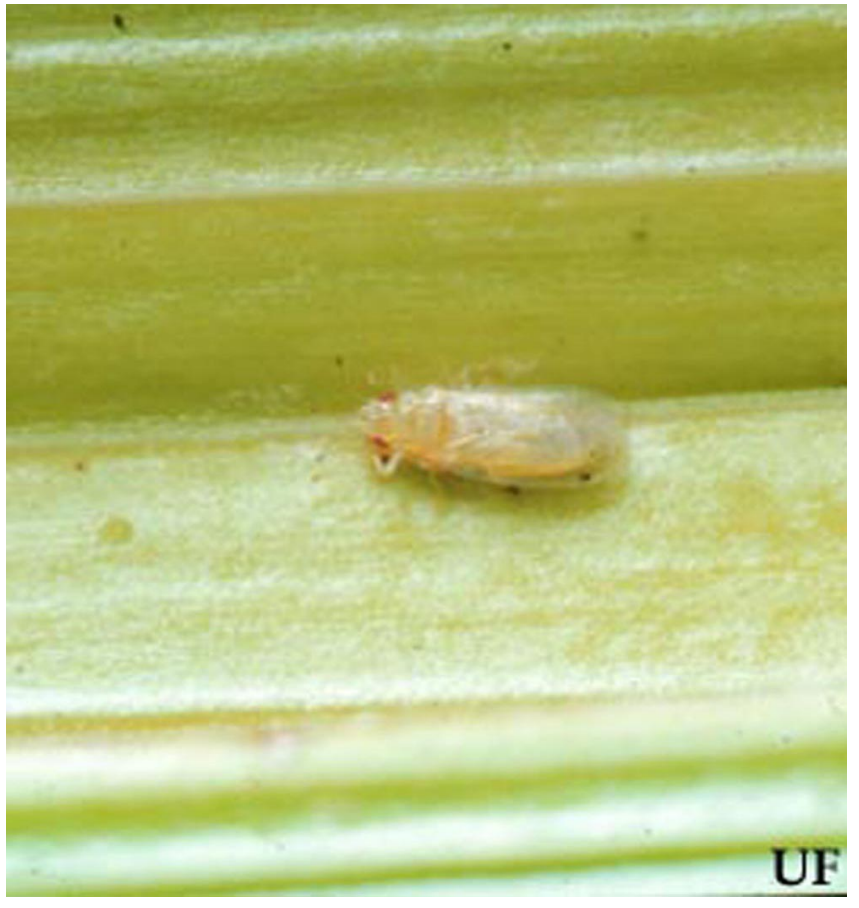

Figure 1. Adult of the royal palm bug, Xylastodoris luteolus Barber. Credits: J. Defilippis, University of Florida

\section{Life Cycle}

Royal palm bug females deposit their eggs in the spring along the midribs of emerging leaflets. At the

1. This document is EENY-097, one of a series of Featured Creatures from the Entomology and Nematology Department, Florida Cooperative Extension Service, Institute of Food and Agricultural Sciences, University of Florida. Published: July 1999. Reviewed: May 2005. This document is also available on Featured Creatures Website at http://creatures.ifas.ufl.edu. Please visit the EDIS Website at http://edis.ifas.ufl.edu. Additional information on these organisms, including many color photographs, is available at the Entomology and Nematology Department WWW site at http://entnemdept.ifas.ufl.edu/. 2. T. J. Weissling, F. W. Howard, and A. W. Meerow, University of Florida, Fort Lauderdale Research Center, Ft. Lauderdale, FL.

The Institute of Food and Agricultural Sciences (IFAS) is an Equal Opportunity Institution authorized to provide research, educational information and other services only to individuals and institutions that function with non-discrimination with respect to race, creed, color, religion, age, disability, sex, sexual orientation, marital status, national origin, political opinions or affiliations. U.S. Department of Agriculture, Cooperative Extension Service, University of Florida, IFAS, Florida A. \& M. University Cooperative Extension Program, and Boards of County Commissioners Cooperating. Larry Arrington, Dean 
time of oviposition, leaflets are folded and the egg is placed inside of the fold. This helps to protect the eggs. Females usually lay only one egg per day, which will hatch in eight or nine days. The time from egg hatch to adult is about one month coinciding with the emergence of new leaves.

\section{Damage}

Royal palm bugs feed on freshly opened leaves causing scattered yellow spots on the lower leaf surfaces. As feeding pressure increases (up to 300 bugs per leaflet have been observed), leaves develop brownish streaks and wilt. Damaged leaves eventually become gray and tattered. Royal palms produce a new leaf monthly, so during the period of royal palm bug activity, about four leaves are damaged. Royal palm bugs rarely, if ever, kill palms but their damage is unsightly and deleterious to the palm's health. Palms less than 12 feet tall are seldom attacked.

Royal palm bugs, though present from year to year, are generally considered to be minor pests. However, severe damage is reported from time to time. Extensive damage due to royal palm bug feeding has been reported throughout southern Florida in the past few years.

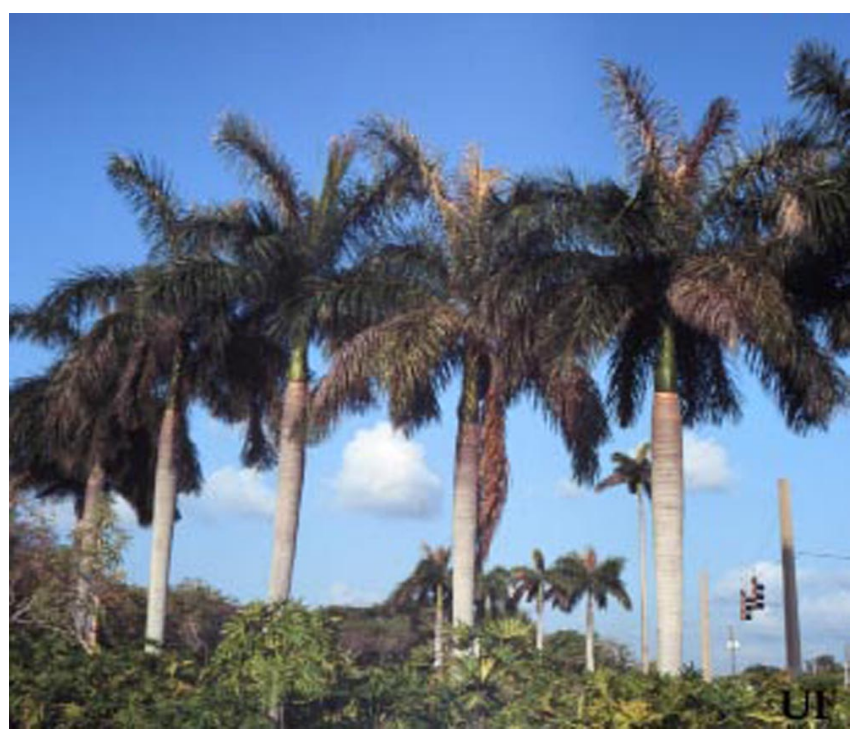

Figure 2. Royal palm bug, Xylastodoris luteolus Barber, damage to a group of royal palms. Credits: F.W. Howard, University of Florida

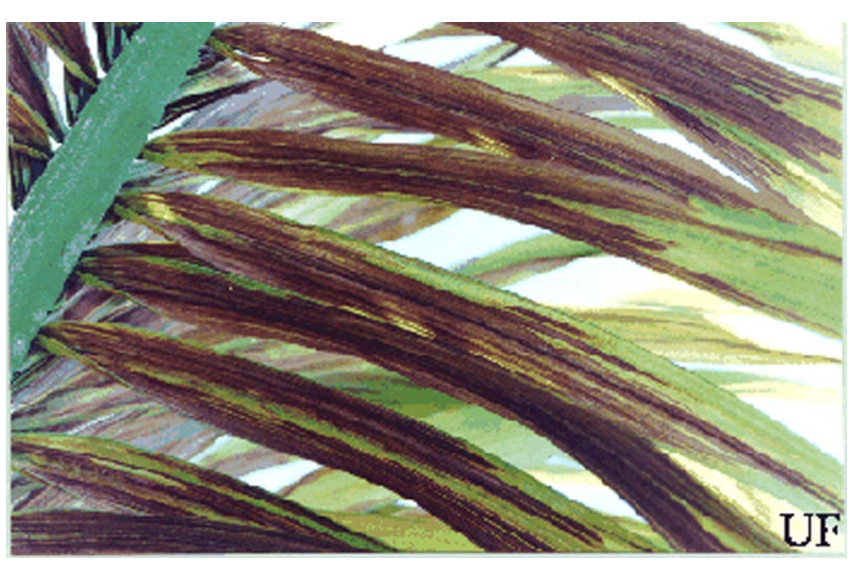

Figure 3. Close up of damage by the royal palm bug, Xylastodoris luteolus Barber. Credits: F.W. Howard, University of Florida

\section{Management}

Other than some general predation by miscellaneous arthropods such as spiders, insecticidal control is the only known reliable method of controlling the royal palm bug in Florida. Chemical control with a contact insecticide can, however, be a challenge due to the height of infested palms and problems with insecticide drift. Root drenches with systemic insecticides are a viable management option because their application does not require special equipment to reach palm leaves. However, leaching of insecticides through the soil into the water table is a concern. Studies indicate that imidacloprid (Merit) applied as a root drench in the late winter at $1 / 2$ ounce per palm, is quite effective for preventing damage to royal palms by the royal palm bug. Imidacloprid remains in the soil for long periods of time and is slowly taken up by the plant to offer prolonged (possibly greater than six months) control potential. Before drenching ( $1 / 2$ to 2 ounces imidicloprid in 5 gallons water), scrap away mulch or grass near the base of the palm, and pour the mixture very slowly around the base of the trunk in a band a few inches wide. If the soil is dry, wet it first with 5 gallons of water before applying the drench.

\section{Selected References}

Baranowski, R.M. 1958. Notes on the biology of the royal palm bug, Xylastodoris luteolus Barber (Hemiptera: Thaumastocoridae). Ann. Entomol. Soc. Amer. 51: 547-551. 
Baranowski, R.M. 1966. The royal palm bug, Xylastodoris luteolus Barber (Hemiptera:

Thaumastocoridae). Florida Dept. Agric., Div. Plant Ind. Enotmol. Circ. No. 46.

Howard, F.W. \& A. Stopek. 1998. Control of royal palm bug with imidicloprid. Principes 42: 80

84.

Meerow, A.W. and T. J. Weissling. Ornamental pest management at the Fort Lauderdale REC. http://www.ftld.ufl.edu/ornapest.htm (July 1999). 